\title{
Geociêncieciass
}

\section{Subvolcanic neck of Cabugi Peak, State of Rio Grande do Norte, Brazil, and origin of its landform}

\section{Neck subvulcânico de Pico do Cabugi, RN, e origem do seu relevo}

\begin{abstract}
Akihisa Motoki
Departamento de Mineralogia e Petrologia Ígnea, Universidade do Estado do Rio de Janeiro rochasornamentais@yahoo.com.br

Thomas Ferreira da Costa Campos

Departamento de Geologia,

Universidade Federal do Rio Grande do Norte tcampos@geologia.ufrn.br
\end{abstract}

\section{Vanildo Pereira da Fonseca \\ Departamento de Geologia, \\ Universidade Federal do Rio Grande do Norte vanildo@geologia.ufrn.br}

\section{Kenji Freire Motoki}

Departamento de Geologia,

Universidade Federal Fluminense

kenjidl@hotmail.com

\section{Resumo}

Esse artigo apresenta as observações geológicas, petrográficas e geomorfológicas do neck subvulcânico de rocha alcalina máfica do Pico do Cabugi, RN. Esse maciço tem $370 \mathrm{~m}$ de altura relativa e cerca de $0.4 \mathrm{~km}^{3}$ de volume total. É constituído, principalmente, pelo Ortognaisse Caicó. O neck está exposto no topo do maciço formando uma saliência cônica de $160 \mathrm{~m}$ de altura relativa e $500 \mathrm{~m}$ de diâmetro. O volume da rocha alcalina máfica é $0,056 \mathrm{~km}^{3}$, ocupando $14 \%$ do maciço. A forma geral do maciço é fortemente convexa com o MCI (Índice de Macro Concavidade) de -2.3. O neck é constituído por álcali microgabro rico em olivina no centro e por álcali dolerito na zona de contato. Observam-se disjunções colunares bem desenvolvidas com diâmetro típico de $60 \mathrm{~cm}$. As disjunções colunares são de alto ângulo no centro do neck e sub-horizontais na zona de contato. Na Planície Sertaneja, não foram observados afloramentos de vala de rochas alcalinas máficas, outros depósitos eruptivos ou debrís de rochas vulcânicas. Essas observações permitem concluir que o edifício vulcânico e os depósitos eruptivos do final do Oligoceno foram removidos completamente pelo soerguimento posterior e consequente denudação regional e que a superfície atual é, significativamente, mais baixa do que aquela da época da erupção. Os afloramentos do Pico do Cabugi exibem a estrutura geológica subterrânea do vulcão do Oligoceno. A morfologia original do vulcão não é mais preservada e a saliência morfológica atual é atribuída à erosão diferencial do neck subvulcânico. Conforme a definição vulcanológica, a morfologia atual do Pico do Cabugi não é classificada como um vulcão extinto.

Palavras-chave: Pico do Cabugi, Rio Grande do Norte, olivina microgabro, neck subvulcânico, magmatismo alcalino de Macau, erosão diferencial.

\footnotetext{
Abstract

This article reports geologic, petrographic, and geomorphological observations of the mafic alkaline subvolcanic neck of the Cabugi Peak, located in the State of Rio Grande do Norte, Brazil. The massif is $370 \mathrm{~m}$ high and has $0.4 \mathrm{~km}^{3}$ of total volume. It is constituted mainly by Caicó orthogneiss. The neck is exposed on the top of the massif forming a conical morphologic protrusion with relative height of $160 \mathrm{~m}$ and diameter of $500 \mathrm{~m}$. The volume of the mafic alkaline rock is $0.056 \mathrm{~km}^{3}$ occupying $14 \%$ of the whole massif. The general form of the massif is strongly convex with the MCI (Macro Concavity Index) of -2.3. The neck is constituted by olivine-rich alkaline micro-gabbro in the centre and alkaline dolerite at the contact zone. There are well-developed cooling columnar joints with typical diameter of $60 \mathrm{~cm}$. They
} 
are steep at the centre of the neck and sub-horizontal at the contact zone. On the foothill surface, called Sertaneja surface, no outcrops of mafic alkaline lava, other eruptive deposits, or volcanic rock debris have been observed. These observations allow a conclusion that the volcanic edifice and eruptive deposits of the late Oligocene were completely removed by later uplift and consequent regional denudation and that the present-day surface is significantly lower than that of the eruption time. The outcrops of the Cabugi Peak exhibit the underground geologic structure of the late Oligocene volcano. The original volcano form is not preserved anymore and the present morphologic elevation is attributed to differential erosion of the subvolcanic neck. According to the volcanological definition, the present-day morphology of the Cabugi Peak is not classified as an extinct volcano.

Keywords: Cabugi Peak, Rio Grande do Norte, olivine micro-gabbro, subvolcanic neck, Macau alkaline magmatism, differential erosion.

\section{Introduction}

The Cabugi Peak (Pico do Cabugi) is located in the central region of the State of Rio Grande do Norte, Brazil, at the coordinates of $\mathrm{N} 05^{\circ} 42.3^{\prime}$, W36 $36^{\circ} 19.3^{\prime}$, about $7 \mathrm{~km}$ to the west of Lages city and $120 \mathrm{~km}$ to the west of Natal city (Figure 1). This massif has $370 \mathrm{~m}$ of relative height and its top exposes a neck of mafic alkaline rocks (Sial, 1978; Silveira et al., 2002). It is a member of the Cenozoic Macau mafic alkaline magma province (Mizusaki, 1989; Souza et al., 2007), which is attributed to a hot-spot track (Sial, 1978). These mafic rocks were studied either in terms of geochemistry or geochronology (e.g. Sial, 1976; 1978; Silveira et al., 2002), having a K-Ar age of 19.7 Ma, whole-rock Ar-Ar age of $23.7 \pm$ 1.2 Ma (Archanjo \& Brito Neves, 2001),
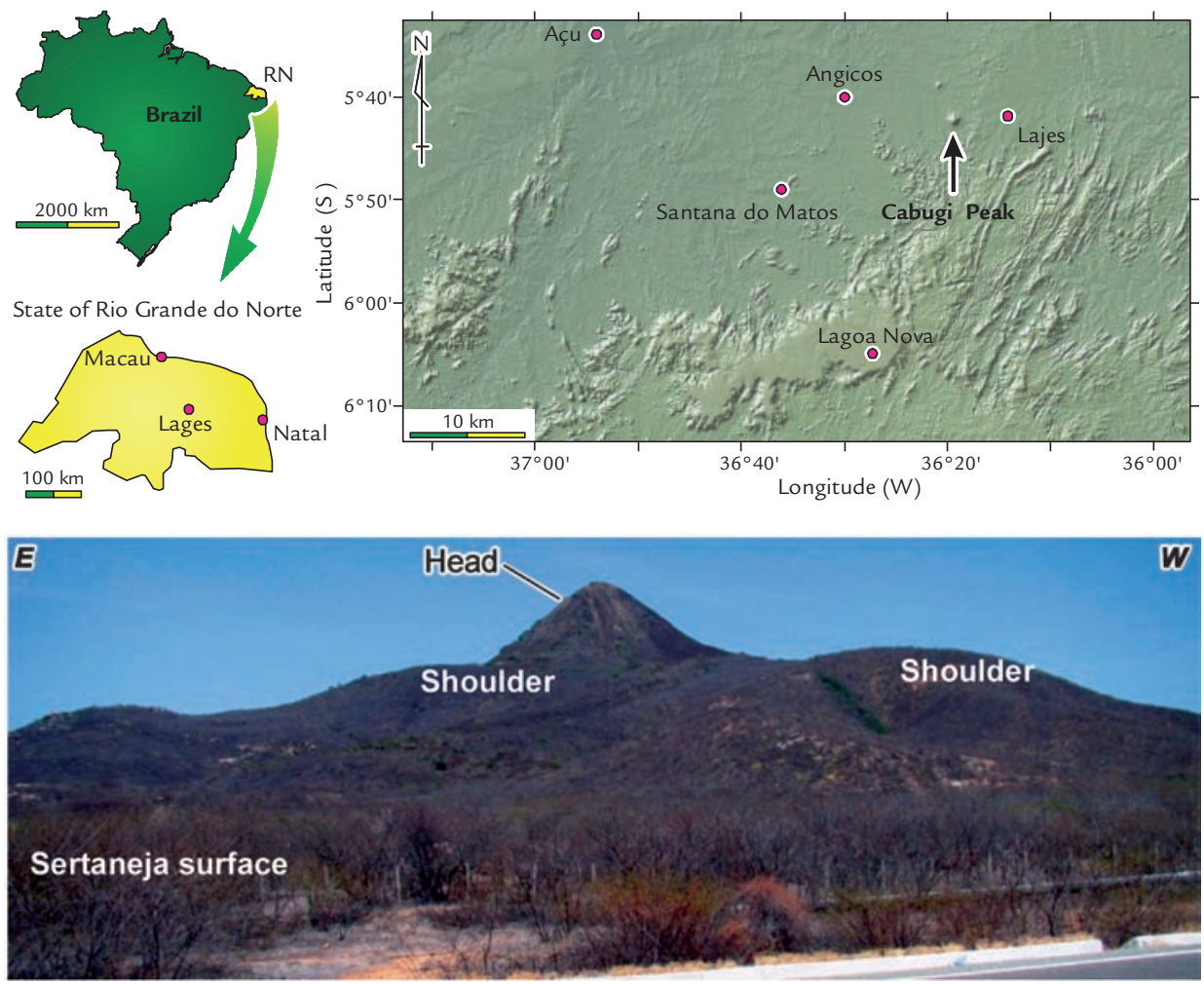

and high accuracy whole-rock Ar-Ar age of $24.6 \pm 0.8 \mathrm{Ma}$ (Souza et al., 2003). Recent Ar-Ar datings show late Oligocene ages, $24.6 \pm 0.8,24.8 \pm 0.3,25.5 \pm 0.4 \mathrm{Ma}$, and $25.5 \pm 0.6$ (Silveira, 2006). The rocks of the Cabugi Peak have normative nepheline, $\mathrm{SiO}_{2}$ varying from $39 \%$ to $45 \%$, and are characterised by enrichment of Ti, K, Sr, and Ba (Souza et al., 2003). The $\mathrm{Sr}$ isotope ratio varies from 0.7039 to 0.7044 (Sial et al., 1981), which indicates their origin from enriched mantle.

The peculiar landform of the Cabugi Peak (Figure 2) seems to be of an extinct volcano. This idea was transmitted mainly by non-academic sources. However, no revised scientific article with volcanological discussions has been published, and therefore, its geologic mode of occurrence

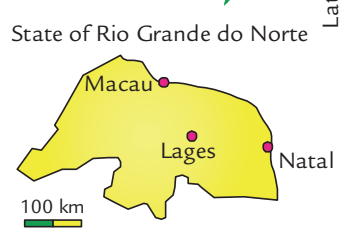




\section{Geomorphological analyses}

For the geomorphological analyses, the authors have adopted digital elevation model of ASTER sensor component of the TERRA satellite, called GDEM (Global Digital Elevation Map), with horizontal resolution of $30 \mathrm{~m}$. In order to express the morphology in a better manner, the drainages narrower than $60 \mathrm{~m}$ wide are virtually filled using summit level technique (Motoki et al., 2008a; 2009a; Fortes et al., 2010). The abovementioned operations have been

Figure 3

Landform of the Cabugi Peak and adjacent area based on the ASTER GDEM:

A) Topographic map.

B) Simplified morphologic model. The drainages narrower than $60 \mathrm{~m}$ are filled virtually by the summit level technique.

Figure 4

Orthogneiss of the Caicó Metamorphic Complex, the basement of the Cabugi Peak mafic alkaline subvolcanic neck:

A) Field occurrence.

B) Photomicrography.

trusion occurs, called "Head". The Head is $500 \mathrm{~m}$ in diameter and 160 $\mathrm{m}$ in relative height, and is made up of mafic alkaline rocks.

According to the pixel counting method (Motoki et al., 2007a), using the original software Wilbur (Motoki et al., 2006), the volume of the Shoulder above the Sertaneja surface is about $0.40 \mathrm{~km}^{3}$ and that of the Head is $0.012 \mathrm{~km}^{3}$. The distribution area for the mafic alkaline rocks is $0.20 \mathrm{~km}^{2}$. The mafic alkaline neck has approximately cylindrical form and it is intrusive into the basement gneiss. The neck volume is $0.056 \mathrm{~km}^{3}$, corresponding to only $14 \%$ of the whole massif (Figure 3B). In case the neck is of performed by the original software system BAZ (Basic Applications of Zenith geomorphological tools) ver. 1.0, build 72 (Motoki \& Motoki, 2011).

The ASTER GDEM shows that the Cabugi Peak is a small mountain, about $370 \mathrm{~m}$ high, standing up on the regional peneplane-like surface with altitude of $180 \mathrm{~m}$, called locally Sertaneja surface (Planície Sertaneja). The highest point is $551 \mathrm{~m}$ above sea level (Figure 3). The Sertaneja surface exposes Archaean to Palaeoproterozo-
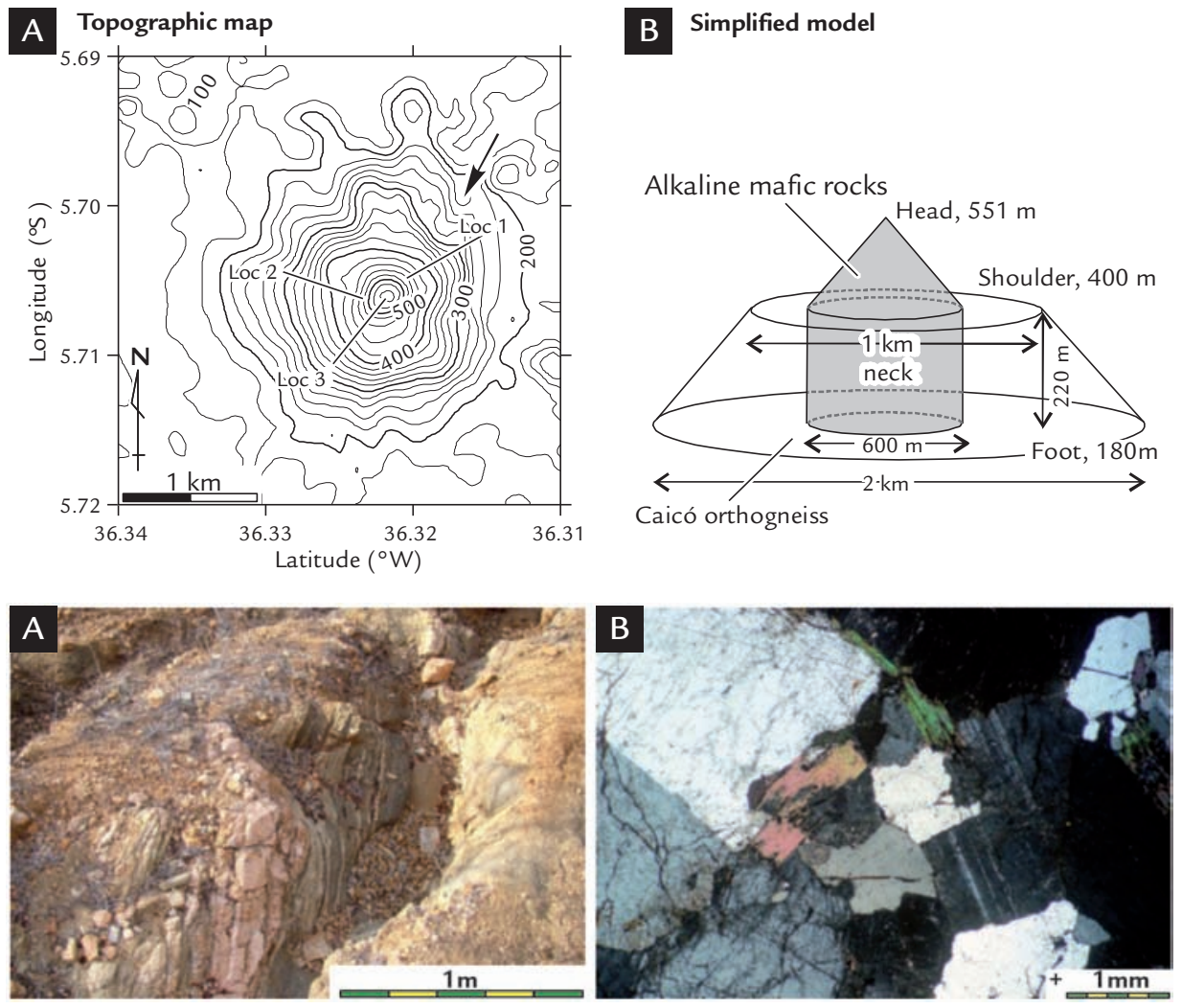

slightly funnel-shaped form, the volume would be smaller. The small distribution area of mafic alkaline rocks is comparable with the other intrusive rock bodies of the Macau magmatic province.

The geomorphological analyses show that the erosion effects of the drainages are small, either on the Shoulder or on the Head. On the Shoulder, the largest drainage is $30 \mathrm{~m}$ deep (Figure 3, arrow). On the Head, no drainage is recognised.

The Macro Concavity Index (MCI; Motoki \& Motoki, 2011) for the Cabugi Peak is strongly negative, being -2.3 , indicating that the massif is remarkably convex in three-dimensional form (Figure 5A). ic high-grade migmatitic orthogneiss of the basement, called Caicó Complex (Souza et al., 1996; Jardim de Sá et al., 1995).

The Cabugi Peak has a circular truncated cone-like general form, socalled "Shoulder" (Figure 4). The diameter of the base circle is $2.0 \mathrm{~km}$ and that of the top circle is $1.0 \mathrm{~km}$. The Shoulder is constituted by migmatitic orthogneiss of the Caicó Complex. On the top of the Shoulder with altitude of $400 \mathrm{~m}$, a conical morphologic pro-

B Simplified model

Caicó orthogneiss

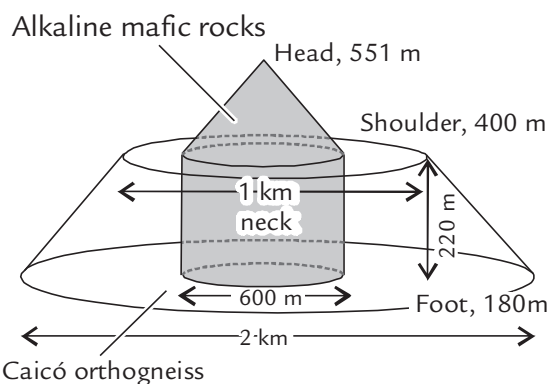

According to the Figure 5B, the active and young volcanoes have slightly positive MCI because of the original stratovolcano landform. When they are eroded, the mountain slope will be more concave and the MCI will be higher.

On the other hand, felsic alkaline rocks are mechanically very firm (Petrakis et al., 2009) and form convex-form massifs with remarkably negative MCI. The MCI value of the Cabugi Peak, -2.3 , is minor than that of the alkaline massifs, suggesting that the massif is of high erosive resistance. This strongly negative MCI is favourable to differential erosion hypothesis, but unsuitable to an eroded extinct volcano. 


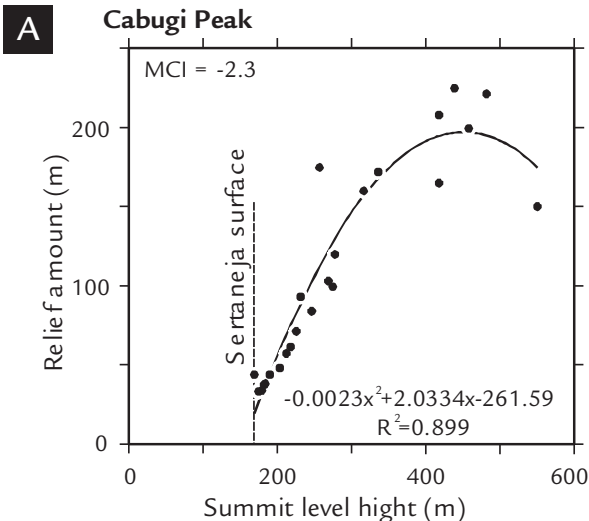

B

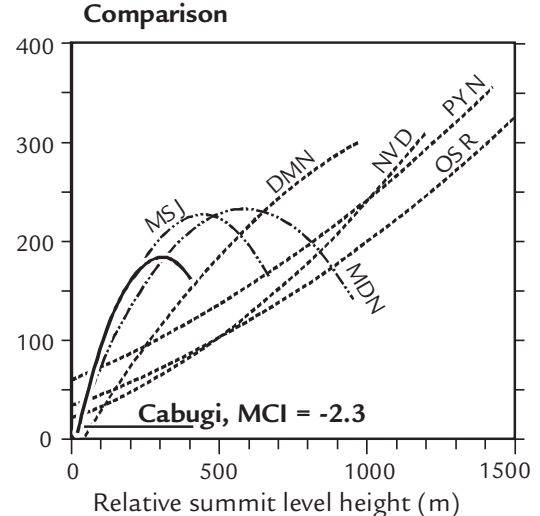

Macro Concavity Index $(\mathrm{MCl})=\mathbf{a} \times 1000\left(y=\mathbf{a x}{ }^{2}+b x+c\right)$ Relief amount (Kifukuryo) = summit level (seppomen) - base level (sekkokumen)

Young volcanoes:

PYN: Payun Liso, $\mathrm{MCl}=0.04$

OSR: Osorno, $\mathrm{MCl}=0.02$

Nephelie syenite massif

MSJ: Morro de São João, $\mathrm{MCl}=-1.2$

MDN: Mendanha, $\mathrm{MCl}=-0.7$

DMN: Diamante, $\mathrm{MCl}=-0.03$

\section{Field observations}

The Head is constituted by mafic alkaline rocks and covered by its blocks with representative size of $60 \mathrm{~cm}$. The slope of the Head is of high angle, about $30^{\circ}$, corresponding to the maximum stability angle for dry solid objects. At some localities, there are outcrops, which are characterised by hexagonal columnar joints, because of removal of the blocks by surface collapse. The largest outcrop, about $60 \mathrm{~m}$ long and $30 \mathrm{~m}$ wide, is located at the northwest slope (Loc. 1, Figure 3A). The columnar joints of the central part of the neck are of high-angle (Figure 6A, arrow $\mathrm{H}$ ), and these of the border zone are of low-angle (Figure 6A, arrow L). The columnar joints close to the contact are sub-horizontal (Loc. 2, Figure 3; 6B).

Lava flows and shallow subsurface intrusive bodies, such as sill, generally have sub-vertical columnar joints, for example: Columbia River Basalt (e.g. Spry, 1962; Long \& Wood, 1986); Devil's Tower, Wyoming (Robinson, 1956); Sheepeater Cliff, Yellowstone National Park (Harris \& Kiver, 1985); Palisades Sill, New Jersey (Spry, 1962); Shiprock, New Mexico, USA (Delaney \& Pollard, 1981); Cerro Re-

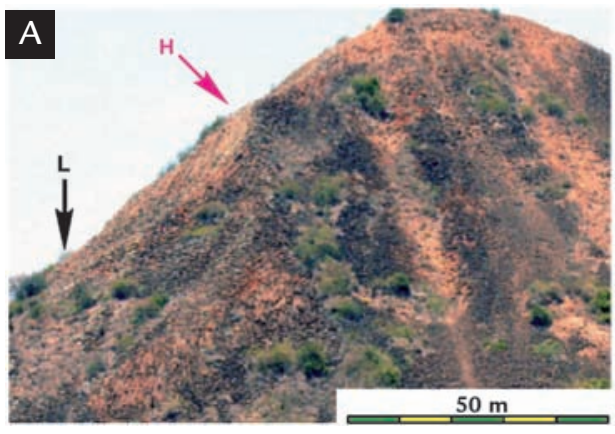

dondo, Santa Cruz, Argentina (Schilling et al., 2005). Vertical columnar joints of lava flows indicate that the magma cooled by surface thermal irradiation.

On the other hand, early Cretaceous tholeiitic dykes of the State of Rio de Janeiro, Brazil, related to the magmatism of the Paraná basaltic province, have well-developed horizontal columnar joints (Motoki et al., 2009b). They were emplaced at a depth of about $5 \mathrm{~km}$ (Motoki \& Sichel, 2008; Motoki et al., 2008b) and cooled by thermal conduction to the dyke wall. Similar Cretaceous tholeiite dykes are exposed on the Sertaneja surface (Angelim et al., 2006), also showing horizontal columnar joints.

The Devil's Tower is an intrusive body of cylindrical form with highly developed vertical columnar joints. On the other hand, the Cabugi Peak has oblique to sub-horizontal columnar joints (Figure 6 ; 8A). The angle of the columnar joints indicates thermal flow direction during the magma cooling (Jiang \& Chen, 2004; Figure 7B). The columnar joint direction indicates that the cooling effect of the Earth's surface is strong for Devil's

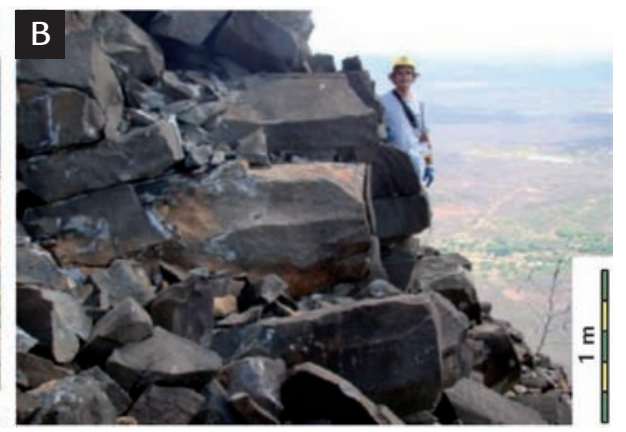

Figure 5

The $\mathrm{MCl}$ diagram for the Cabugi Peak according to the method of Motoki \& Motoki (2011): A) Projection of summit level vs. the difference between summit level and base level of grid interval of 480 m; B) MCl for the Cabugi Peak compared with young volcanoes and nepheline syenite intrusive massifs. OSR - Osorno Volcano, Chile; PYN - Payún Liso Volcano, Argentina; DMN - Cerro de Diamante Volcano, Argentina; NVD - Nevado Volcano, Argentina; MDN - Mendanha nepheline syenite massif, Brazil; MSJ Morro de São João nepheline syenite massif, Brazil.

Tower but that for the Cabugi Peak is less expressive. In this sense, the Cabugi Peak subvolcanic neck could have been emplaced at a site deeper than the Devil's Tower, but not as deep as tholeiite dykes with horizontal columnar joints.

The block layer on the Head is 5 to $10 \mathrm{~m}$ thick and it is composed of angular mafic alkaline rocks. They are originated from the columnar joints and have hexagonal column form (Figure 8A). Many blocks have fresh fragmentation surfaces. The Shoulder top generally exposes orthogneiss of the Caicó Complex, but is covered by mafic alkaline blocks at few localities (Figure 8B). The blocks on the Shoulder tend to be slightly rounded (Figure 8C), showing node rounding. However, hexagonal edges are often preserved. These observations indicate that the block tumbling is still very active and the Head is in on-going surface collapse process. The neck was exposed at the surface in a recent geologic time.

On the other hand, no outcrops of mafic alkaline lava, pyroclastic eruptive deposits or volcanic rock debris have been observed. The foothill of the Sertaneja

Figure 6

Columnar joints of the mafic alkaline rock at the Head of the Cabugi Peak, State of Rio Grande do Norte, Brazil: A) Transition from high-angle joint at the central part of the neck (arrow $\mathrm{H}$ ) to low angle ones at the border (arrow L). B) Horizontal columnar joints close to the contact. 
Figure 7

Direction change of columnar joints: A) The Cabugi Peak neck, State of Rio Grande do Norte, Brazil, schematic illustration of the authors.

B) Lütao dyke-lava system, Pengfu Islands, Taiwan (Jiang \& Chen, 2004).

Note the similarity between the columnar joint of the Cabugi Peak and dyke part of the Lütao intrusive body.

Figure 8

Mafic alkaline rock blocks covering the Head:

A) High-angle slope of the Head covered by hexagonal and fragmented angular blocks.

B) View from the top of the Head showing the surface of the Shoulder covered partially by the blocks.

C) Slightly rounded blocks on the Shoulder.

D) Linear and polygonal cooling cracks (black arrows).

surface exposes the Caicó Complex orthogneiss and tholeiitic dykes intruded in a deep site. If the Cabugi Peak were an extinct volcano, the above-mentioned volcanic materials must be abundantly present on the Sertaneja surface, especially at the localities close to the Cabugi Peak.

The contact plane between the neck and its country body is a most important subject to be observed, but during the fieldwork no adequate outcrop has been found. Sub-horizontal columnar joints at the contact zone suggest that the contact is sub-vertical. All of the columnar joints

Figure 9

Peculiar fabrics of the mafic alkaline rock blocks: A) Olivine-rich xenoliths (red arrows). B) Polygonal cooling crack on the lateral surfaces of a hexagonal columnar joint.
Hydrothermal ophitic gabbro
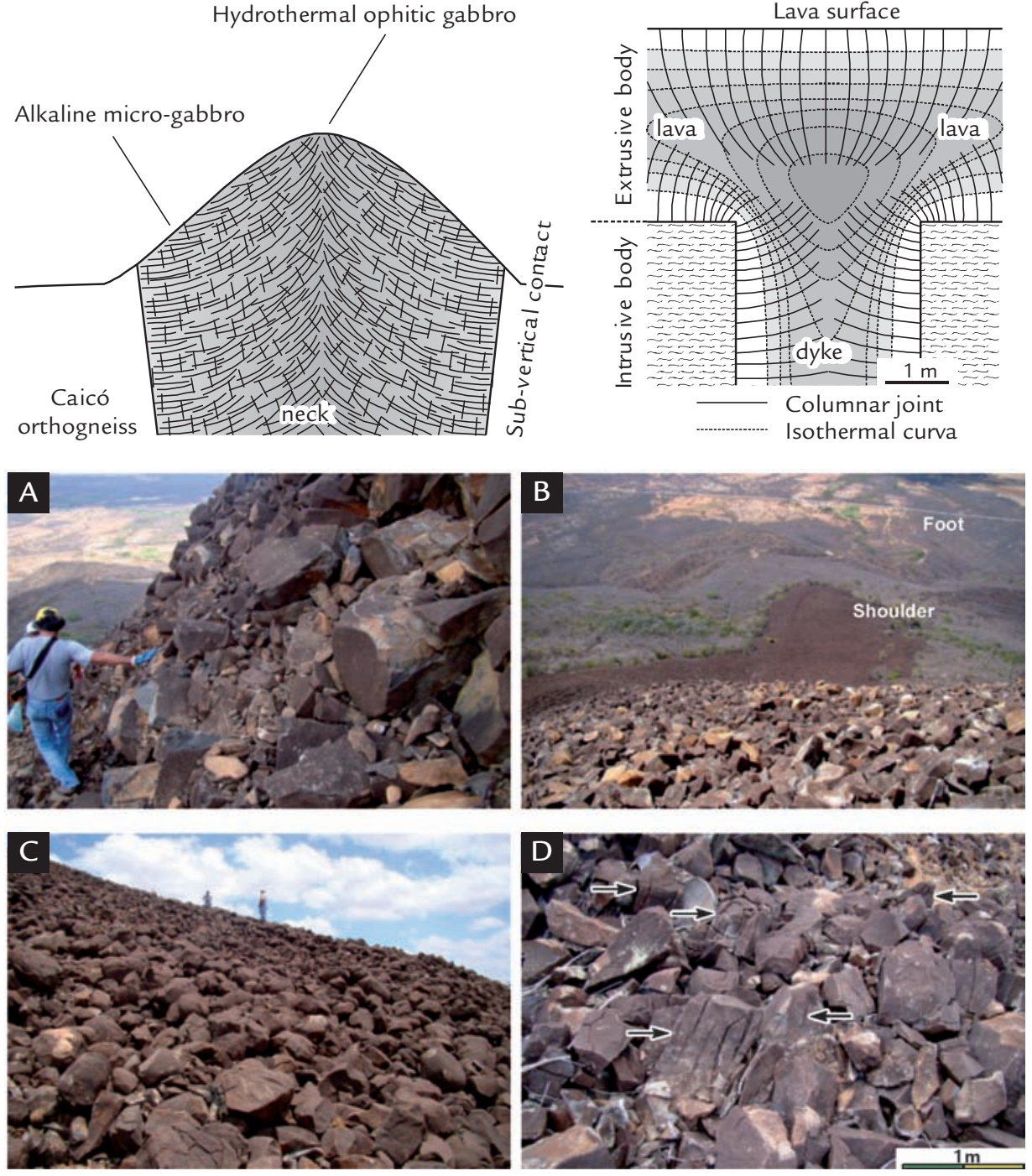

are tilted largely or slightly to the centre of the neck. This observation suggests that the contact plane is of slightly funnelshaped three-dimensional form, that is, the neck could be open upward. If so, the abundance of the mafic alkaline blocks on the Head is easily explained.

Macroscopically, the mafic alkaline rocks are relatively coarse-grained, with grain-size of about $1 \mathrm{~mm}$, and contain olivine-rich mantle xenoliths less than 2 $\mathrm{cm}$ in size (Figure 9A). There are blocks with linear cracks and curved polygonal crack like turtle's carapace (Figure 8D,

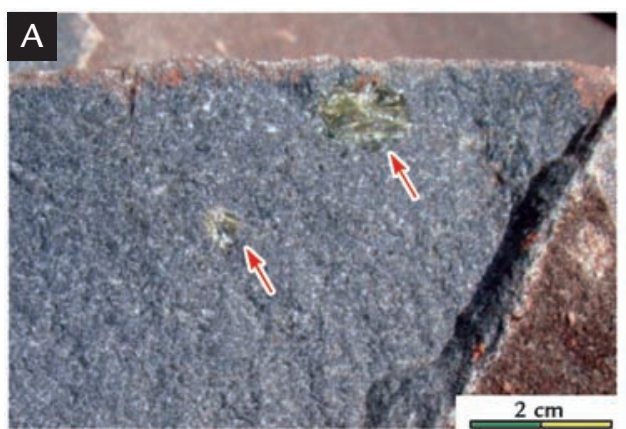

arrows). Some of them are apparently similar to bread-crust bomb (Figure 9B). These fractures occur only on lateral surfaces of the columnar joints and originated from surface volume contraction by rapid cooling along columnar joint planes (Figure 10).

Bread-crust bombs are characterised by: 1) Volume expansion; 2) Porous texture by vesicular formation; 3) Elliptic form (e.g. MacDonald, 1972); 4) Vitric; 5) Andesite do dacite composition. The blocs of the Cabugi Peak are featured by: 1) Volume contraction; 2) Massive texture

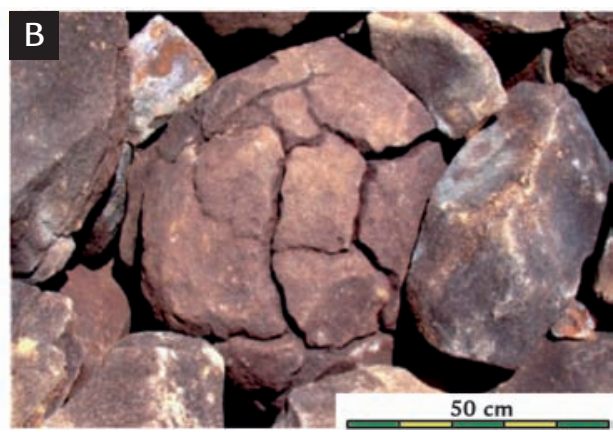


without vesicles (Figure 9A); 3) Hexagonal column form; 4) Holocrystalline; 5) Mafic to ultramafic composition. Therefore, the above-mentioned mafic rock blocks

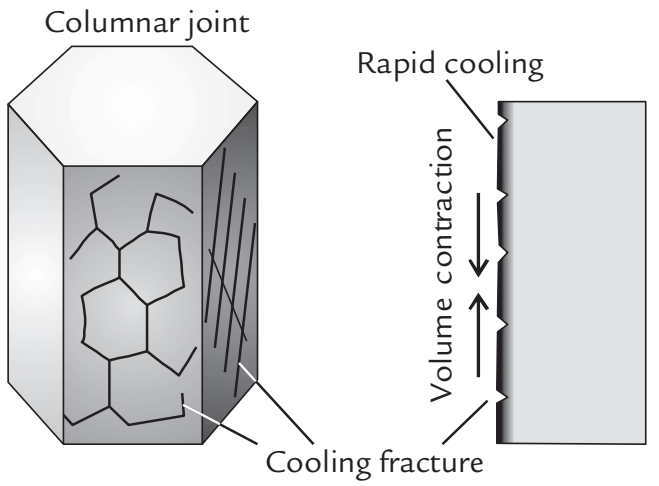

(Figure 9B) are not considered to be breadcrust bombs.
Figure 10

Schematic illustration for the polygonal cooling crack of columnar joint of the Head of the Cabugi Peak.

\section{Petrographic observations}

The mafic alkaline rocks of the Head are made up of olivine, clinopyroxene, plagioclase, opaque minerals, and apatite (Figure 11). According to Sial et al. (1981), the $\mathrm{SiO}_{2}$ contents are 39 45wt\%, which correspond to picritic alkaline gabbro of ultrabasic category. In spite of ultrabasic composition, there rocks are not ultramafic.

Olivine occurs either as phenocrysts of $1.0 \mathrm{~mm}$ in diameter, or in the groundmass. Some large olivine crystals show resorption texture (Figure 11D). The clinopyroxene is titanoaugite and $0.2 \mathrm{~mm}$ to $0.4 \mathrm{~mm}$ in size (Figure 11B). Plagioclase takes place as large tabular crystals (Figure 11A) and microliths (Figure 11B, C).

There is a notable textural contrast between the central part of the neck and
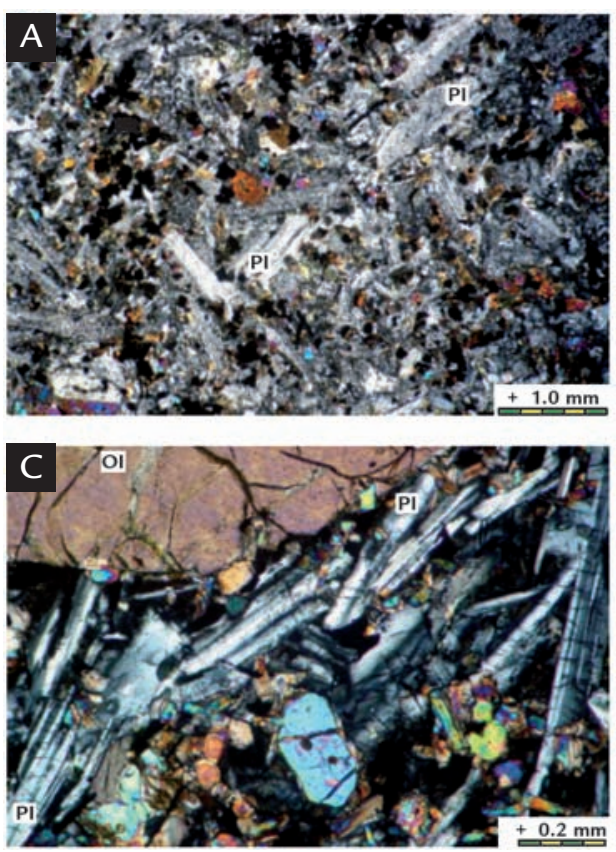

\section{Extinct volcano or shallow intrusive body?}

The idea of the Cabugi Peak as an extinct volcano was proposed by Moraes
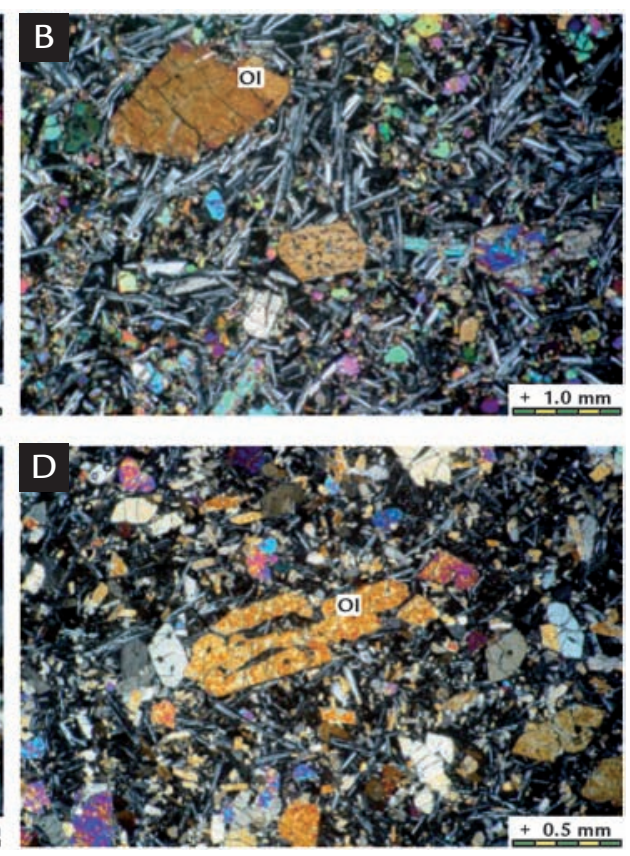

the contact zone. The sample of the centre is relatively coarse-grained (Figure 11A). The plagioclase crystals are $1.5 \mathrm{~mm} \times 0.4$ $\mathrm{mm}$ in size, and the rock is classified to be olivine-rich micro-gabbro. Alteration of large plagioclase crystals and partial decomposition of the mafic minerals into opaque ones are notable. These features suggest metasomatic or hydrothermal alteration, which is commonly observed in the central part of alkaline rock dykes (Motoki et al., 2008b).

The sample of the contact zone is holocrystalline and relatively fine-grained (Figure 11B). According to the crystallinity and grain size, it is classified to be olivinerich dolerite. In contrast to the central part of the neck, the rock is fresh without signs

(1924). He considered that the present morphology is originated directly from of alteration. The texture is sometimes not typically porphyritic. It is characterised by intermediate-sized olivine and clinopyroxene crystals. The plagioclase microliths are $0.08 \mathrm{~mm} \times 0.4 \mathrm{~mm}$ (Figure 11C).

Some of the olivine crystals show sign of remelting (Figure 11D) but most of them are idiomorphic without remelting. This observation suggests two different origins. Considering the existence of olivine-rich mantle xenoliths (Figure 9A), the re-melted olivine could be originated from the xenolith. On the other hand, the idiomorphic ones are phenocrysts.

These observations confirm basically the previous description (e.g. Sial et al., 1981; Ferreira \& Sial, 1999), but no volcanic glass is recognised.

Figure 11

Photomicrography of the Cabugi

Peak mafic alkaline rocks:

A) Central part of the neck.

B) Contact zone of the neck.

C) Tabular plagioclase of the sample B.

D) Olivine with resorption texture.

$\mathrm{Ol}$ - olivine; $\mathrm{Pl}$ - plagioclase. the volcanic edifice without notable erosive effects (Figure 12A). That is, the late 
Oligocene volcanic landform is almost perfectly preserved up to the present. Most of the non-academic sources (e.g. Rocha \& Nascimento, 2007; Barros, 2009; Jornal do Turismo, 2011) adopted this opinion and call it as "the only one Brazilian extinct volcano with preserved original form".

Souza et al. (2002), Paiva et al. (2004), and Nascimento et al. (2006) accepted the volcano model, but with some modifications. There was a volcanic edifice larger than present morphology of the Cabugi Peak and its lateral slope was deeply eroded remaining the central conduit filled by magma, that is, neck (Figure 12B). The original volcanic landform is no more preserved. These authors used the term "neck" as the conduit filled by consolidated magma at the centre of the volcanic edifice, that is, cylindrical magma feeder above the surface level of the eruption time. However, the geologic term "neck" corresponds to the cylindrical magma feeder either above or under the original surface (MacDonald, 1972). In order to distinguish the both types, the authors adopt the expression "neck in the

volcanic edifice" for the former (Figure 12B) and "subvolcanic neck" for the latter (Figure 12C).

The models A and B of Figure 12 consider that the Cabugi Peak is an extrusive volcanic rock body. In addition, the surface of the Oligocene was the same of the present, without regional denudation. Therefore, the present position of the Cabugi Peak is above the surface of the eruption time. Rolff (1965) and Sial (1978) described it as a neck or plug. But no clear model for the geologic emplacement was expressed.

A

Volcano

Without erosion, without denudation

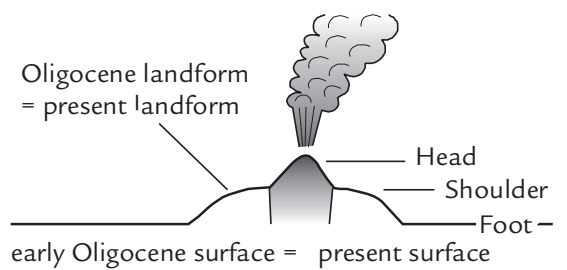

B Eroded volcano

With erosion, without denudation

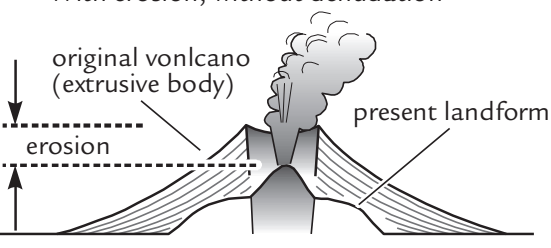

early Oligocene surface $=$ present surface

Figure 12

Comparative illustration of the models

for geologic emplacement mode of the

Cabugi Peak mafic alkaline rock body:

A) Preserved extinct volcano (Moraes, 1924).

B) Eroded volcanic edifice (e.g. Souza et al., 2002;

Paiva et al., 2004; Nascimento et al., 2006).

C) Subvolcanic neck, proposal of the present paper.

The present study has clarified that the Cabugi Peak neck is characterised by: 1) Cylindrical or slightly funnel-shaped three-dimensional rock body form; 2) High-angle columnar joints at the centre of the neck and sub-horizontal ones, at the contact zone; 3) Centre of the neck constituted by olivine-rich micro-gabbro and the border, by olivine-rich dolerite; 4) Distribution of the mafic alkaline rock in very restrict, in an area of $0.20 \mathrm{~km}^{2} ; 5$ ) Absence of mafic alkaline lava, eruptive deposits, and volcanic rock debris on the Foot plane of the Sertaneja surface; 6) The three-dimensional form of the massif is strongly convex, with strongly negative MCI of -2.3 .
The models of volcano and eroded volcano (Figure 12A, B) have incompatibilities with the present observations. The magma of the Cabugi Peak is of ultrabasic composition and has low viscosity and high fluidity. If the Cabugi Peak were an extinct volcano, the eruptive materials, such as lava flow and pyroclastic deposits, should be present extendedly on the Sertaneja surface. In addition, the blocks originated from the eroded part of the volcanic edifice should be present abundantly. However, in fact, no such materials have been observed. The strictly limited distribution area is unfavourable to an extinct volcano hypothesis.

If the Head were the central conduit
C Subvolcanic neck Deep denudation

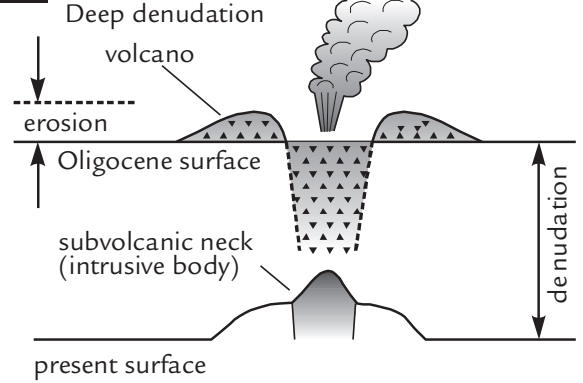

in the volcano, that is, the neck in the volcanic edifice, the Shoulder must be a part of the volcanic edifice (Figure 12B). However, the Shoulder is made up of the Caicó orthogneiss. If the mafic alkaline rocks were constituent of an extrusive body, the rocks should be vitric or very fine-grained and porous, and the columnar joints should be vertical. However, the rocks are holocrystalline massive micro-gabbro or dolerite and the joints are sub-horizontal at the contact zone.

If the Cabugi Peak were eroded volcanic edifice and not a morphological elevation originated from differential erosion of a subvolcanic intrusive body, the general massive form should be concave 
and the MCI should be positive. However, its three-dimensional form is convex, with a strongly negative MCI, of -2.3 . These facts indicate that the Cabugi Peak neck is not an extrusive body at the surface, but an intrusive one emplaced at an underground site.

Ferreira \& Sial (1999) interpreted the blocks with polygonal cooling fractures on the lateral surfaces of the columnar joint (Figure 8D, 10B) as bread-crust bombs. Such bombs are formed by volume expansion by vesiculation of vitric essential fragments, that is, the magma drops ejected from the crater in consolidation process. However, the blocks in question are holocrystalline and massive, and not, vitric and porous. Bread-crust bomb occurs in the eruption of high viscosity magmas, such as andesitic, dacitic, and trachytic ones, represented by Vulcanian eruption (MacDonald, 1972). However, the blocks of the Cabugi peak are constituted by holocrystalline olivine-rich alkaline micro-gabbro or dolerite of ultrabasic composition, and therefore, such magma cannot generate bread-crust bomb.

Considering the previous discussions, the authors propose a subvolcanic

\section{Interpretation of eruption mode}

Low viscosity magmas, such as of alkaline olivine gabbro, rise up in the upper crust by means of dyke intrusion. When the magmas arrive at the surface, a fissure eruption takes place. In this case, large cylindrical conduits, such as the Cabugi subvolcanic neck, are unnecessary.

Cylindrical or slightly funnel-shaped subvolcanic conduits are formed by explosive eruptions. Some mafic to ultramafic alkaline magmas have high fluid contents neck model for the Cabugi Peak. The Earth's surface of eruption time of the late Oligocene was not the same height of the present regional level of the Sertaneja surface, but it was much higher. The volcanic edifice was emplaced on this previous surface. However, later regional uplift and consequent deep denudation removed completely the volcanic edifice and eruptive deposits. At the present, only the underground conduit is left as a subvolcanic neck (Figure 12C).

The Sertaneja surface has wide and shallow morphologic depressions originated from lateral river erosion. The surface is close to be an elevated peneplane but it is not completely in erosive equilibrium. In this sense, the regional denudation is still active in spite that it is not so strong.

The model of the Figure $12 \mathrm{C}$ is similar to that of the alkaline intrusive complexes with pyroclastic bodies of the State of Rio de Janeiro, such as Mendanha (Motoki et al., 2007b), Itaúna (Motoki et al., 2008c), Tanguá, Rio Bonito, Soarinho (Motoki et al., 2010), Morro dos Gatos (Motoki et al., 2011), and Cabo Frio Island (Sichel et al., 2008). The original surface

and it causes explosive eruption forming tuff volcano and upward opened funnel-shaped conduits called diatreme (Figure 13A). When a large amount of magma is provided just after the explosive eruption, the diatreme vent space is filled by magma (Figure 13B).

After the eruption, deep regional denudation occurred. The volcanic edifice, eruptive deposits, and the surface of eruption time have been removed, remaining only the subvolcanic neck. The has been removed by later uplift and consequent regional denudation. The magma chambers and subvolcanic conduits $3 \mathrm{~km}$ below the prior surface are exposed at the present-day surface (e.g. Motoki \& Sichel, 2006; Motoki et al., 2008d).

The geologic expressions "volcano" and "volcanic edifice" are defined as a morphologic elevation formed directly by eruptions and consequent accumulation of eruptive materials on the Earth's surface (e.g. MacDonald, 1972; Bates $\&$ Jacson, 1987). The positive relieves originated from differential erosion of intrusive bodies, such as dyke and subvolcanic neck, are not classified to be extinct volcanoes.

For example, the Chachahuén Volcano and the Plateado Volcano, Mendoza Province, Argentina are deeply eroded stratovolcanoes (Bermudez et al., 1993). In spite of the strong erosion effects, the denudation is null. The surface of the eruption time is the same of the present. The present-day topographic elevations are directly delivered from volcanic edifices and not because of differential erosion. Therefore, they are classified to be eroded extinct volcanoes.

\section{Conclusion}

The Cabugi Peak was reported as the only one Brazilian extinct volcano with preserved original form. However, the present study leads to a different conclusion. Field observations, geomorphological analyses, petrographic descriptions, and volcanological consideration of the Pico do Cabugi indicate the following conclusions:

1. The Cabugi Peak is $370 \mathrm{~m}$ high, has a volume of $0.4 \mathrm{~m}^{3}$, and is made up mainly of basement orthogneiss of the Caicó Complex. The neck is exposed on its top forming a conical morphologic protrusion of 160 $\mathrm{m}$ of relative height and $500 \mathrm{~m}$ of diameter. The volume of the mafic alkaline rock is $0.056 \mathrm{~km}^{3}$ occupying $14 \%$ of the whole massif. The massif has remarkably convex general form and the MIC is -2.3. This strongly negative $\mathrm{MCI}$ is favourable to differential erosion hypothesis, but unfavourable to eroded extinct volcano one.

2. The neck is characterised by welldeveloped columnar joints with typical diameter of $60 \mathrm{~cm}$. They are steep at the centre of the neck and sub-horizontal at the contact zone. present erosion base level is situated at the Sertaneja surface and it is much lower than the old surface. The outcrops of the Cabugi Peak correspond to the subvolcanic structure of the eruption time and the subvolcanic neck is an intrusive body. The morphological relief of the Head is formed by differential erosion of the subvolcanic neck (Figure 13C). This is a possible interpretation without contradiction with the field evidences.
The sub-horizontal columnar joints suggest that this neck is not an extrusive body, but a shallow intrusive one. The fragments originated from the columnar joints cover the surface of the neck. The fractures similar to those of bread-crust bomb are formed by rapid cooling on the hexagonal planes of columnar joints.

3. The neck is constituted by olivinerich micro-gabbro of $1.5 \mathrm{~mm}$ in grain size at the central part and olivinerich dolerite of $0.4 \mathrm{~mm}$ at the border. The rock is holocrystalline and massive, without porous structure. 
4. No outcrop of lava flow of the mafic alkaline rocks, eruptive deposits, or volcanic debris is observed on the Foot plane of the Sertaneja surface. The mafic alkaline rock occurs only on the Head in an area of $0.2 \mathrm{~km}^{2}$. This limited distribution is favourable to subvolcanic neck model. The volcanic edifice and eruptive deposits of the late Oligocene were completely removed by later denudation caused by regional uplift and the original landform of volcanic edifice is not preserved any more.

5. The present-day exposure of the Cabugi Peak corresponds to a subvolcanic neck, being a shallow intrusive body, and not a neck in the volcanic edifice. The topographic high is attributed to differential erosion. According to the geologic definition, the Cabugi Peak is not classified to be an extinct volcano because of the total elimination of the original volcanic edifice and eruptive deposits.

6. Geologic setting of the Cabugi Peak suggests the following eruption history; 1) Explosive eruption took place forming tuff-ring and diatreme; B) Diatreme vent was filled by mafic alkaline magma forming a cylindrical intrusive body; C) Regional denudation exposed the underground structure and differential erosion made the morphologic elevation of the subvolcanic neck.

A Diatreme explosion
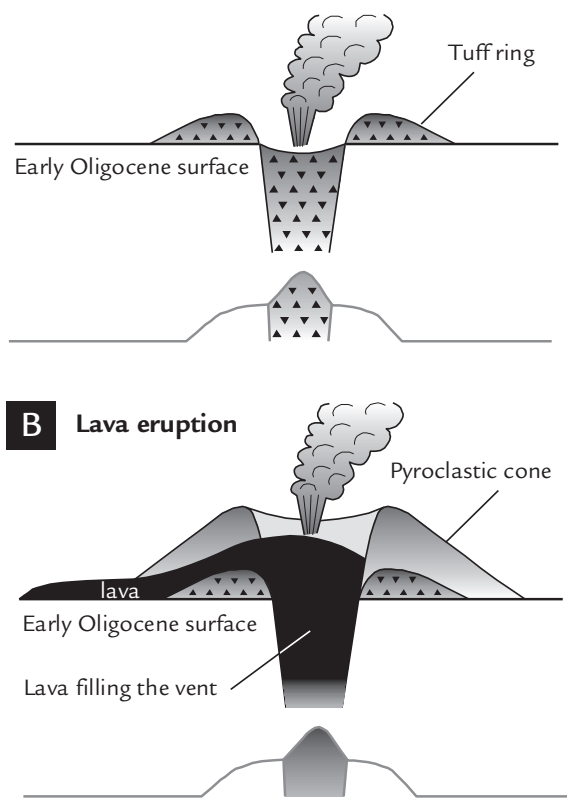

C Regional denudation

Figure 13

Schematic illustration of the model for the

formation process of the Cabugi Peak:

A) Explosive eruption and formation of tuff-ring and diatreme.

B) Diatreme vent filled by magma.

C) Regional denudation exposing the subvolcanic structure.

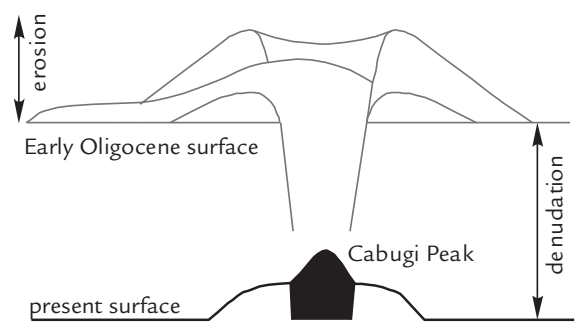

\section{Acknowledgement}

The vehicle and fuel for the fieldwork are provided by the Universidade Federal do Rio Grande do Norte. The

instruments of the informatics are supported by the FAPERJ, Carlos Chagas Filho Foundation, of the Rio de Janeiro
State Government. The ASTER GDEM data are offered by ERSDAC, Japan. The authors are grateful to these institutions.

\section{References}

ANGELIM, L.A.A., NESI, J.R., TORRES, H.H.F., MEDEIROS, V.C., SANTOS, C.A., VEIGA JUNIOR, J.P., MENDES, V.A., OLIVEIRA, P.G., SAMPAIO, M.A., ARAÚJO, R.B. Geologia e recursos minerais do Estado do Rio Grande do Norte. Texto explicativo dos mapas geológico e de recursos minerais do Estado do Rio Grande do Norte, Escala 1:500.000. CPRM (Brazilian Geological Survey), 2006. 119p.

ARCHANJO, C.J., BRITO NEVES, B.B. Idades ${ }^{40} \mathrm{Ar} /{ }^{39} \mathrm{Ar}$ do magmatismo básico Meso-Cenozóico da Província Borborema Oriental, Nordeste do Brasil. Boletim 
de Resumos do $19^{\circ}$ Simpósio de Geologia do Nordeste. Natal, Sociedade Brasileira de Geologia, p. 260-261, 2001.

BARROSRROS, C. Trilha ecológica do Pico do Cabugi. Geotrilhas, 2009. http:// www.geotrilhas.blogspot.com/2009/09/trilha-ecologica-do-pico-do-cabugi.html, Acess: May 14, 2011.

BATES, R., JACSON, J.A. Glossary of Geology, 3rd edition. McGraw-Hill Book Company, 1987. 788 p.

BERMUDEZ, A., DELPINO, D., FREY, F., SALL, A. Los basaltos extraandinos. In: CONGRESO GEOLÓGICO ARGENTINO, 12. Relatorio de la. Asociación Geológico Argentino, v. 1, p. 161-172, 1993.

DELANEY, P.T., POLLARD, D.D. Deformation of host rocks and flow of magma during growth of Minette dikes and breccia-bearing intrusions near Ship Rock, New Mexico, Bulletin of the United State Geological Survey, Professional Paper, n. 1202, 1981.

FERREIRA, V.P., SIAL, A.N. Pico do Cabugi, RN. Registro do mais jovem magmatismo continental do Brasil. SIGEP-Sítios Geológicos e Paleobiológicos, v. 39, p. 393-398, 1999.

FORTES, E., OLIVEIRA, S.B., VOLKMAER, S. Aplicações da técnica de seppômen na análise paleoclimática e morfoestrutural: o caso da bacia hidrográfica do Rio São Pedro - Faxinal, PR. In: SEMINÁRIO LATINO AMERICANO DE GEOGRAFIA FÍSICA, 6 e SEMINÁRIO IBERO AMERICANO DE GEOGRAFIA FÍSICA, 2. Anais... Portugal: Universidade de Coimbra, 2010. 12p. CD.

HARRIS, D.V., KIVER, E.P. The geologic story of the national parks and monuments. John Wiley \& Sons, Inc. 1985. 464p.

JARDIM DE SÁ, E.F.J., FUCK, R.A., MACEDO, M.H.F., PEUCAT, J.J., KAWASHITA, K., SOUZA, Z.S., BERTRANDT, J.M. Pre-Brasiliano orogenic evolution in the Seridó Belt, NE Brazil: Conflicting geochronological and structural data. Revista Brasileira de Geociencias, v. 25, n.4, p. 307-314, 1995.

JIANG, W.S., CHEN, J.C. The topographic landscape of volcanic necks of the Coastal Range and Lutao, eastern Taiwan. Taiwan Academy of Science, Taipei, v. 17, p. 82-92, 2004.

JORNAL DO TURISMO. Peito da Moça. Destino do Sol, Jornal do Turismo, Brasil. http://www.destinodosol.com.br/html/destinos/sertao_e_agreste/sertao_e_ agreste_12.html. Acess: May, 11, 2011.

LONG, P.E., WOOD, B. Structures, textures, and cooling histories of Columbia River basalt flows. Geological Society of America Bulletim, v. 97, n. 9. p. 1144-1155, 1986.

MACDONALD, G.A. Volcanoes. Prentice-Hall, Englewood Cliffs, 1972. 510 p.

MIZUSAKI A.M.P. A Formação Macau na porção submersa da bacia Potiguar. Boletim de Geociências da Petrobras, v.3, p. 191-200, 1989.

MORAES, L.J. Serras e Montanhas do Nordeste. Ministério de Viação e Obras Públicas, Publicação 58, Série I.D., 123p, 1924.

MOTOKI, A., MOTOKI, K.F. Origem dos relevos do maciço Mendanha, RJ, movimento de falhas ou erosão diferencial?: análises geomorfológicas por seppômen e sekkokumen com base do ASTER GDEM. In: SIMPÓSIO NACIONAL DE ESTUDOS TECTÔNICOS, 13. Anais... Campinas, SBG, CD, 378-381, 2011.

MOTOKI, A., SICHEL, S.E. Avaliação de aspectos texturais e estruturais de corpos vulcânicos e subvulcânicos e sua relação com o ambiente de cristalização, com base em exemplos do Brasil, Argentina e Chile. REM-Revista Escola de Minas, Ouro Preto, v. 59, n. 1, p. 13-23, 2006.

MOTOKI, A., SICHEL, S.E. Hydraulic fracturing as a possible mechanism of dykesill transitions and horizontal discordant intrusions in trachytic tabular bodies of Arraial do Cabo, State of Rio de Janeiro, Brazil. Geofísica Internacional, Mexico City, v. 47, v. 1, p. 13-25, 2008.

MOTOKI, A., ZUCCO, L.L., SICHEL, S.E., AIRES, J.R., PETRAKIS, G.H. Development of the tecnique for digital colour specification and the new nomenclatures of ornamental rock based on the measured colours. Geociências, Rio Claro, v. 25, n. 4, p. 403-415, 2006.

MOTOKI, A., PETRAKIS, G.H., SOARES, R., SICHEL, S.E., AIRES, J.R. New method of semi-automatic modal analyses for phenocrysts of porphyritic rocks based on quantitative digital colour specification technique. REM-Revista Escola de Minas, Ouro Preto, v. 60, n. 1, p. 13-20, 2007a. 
MOTOKI, A., SOARES, R., NETTO, A.M., SICHEL, S.E., AIRES, J.R., LOBATO, M. Genetic reconsideration of the Nova Iguaçu Volcano model, State of Rio de Janeiro, Brazil: eruptive origin or subvolcanic intrusion? REM-Revista Escola de Minas, Ouro Preto, v. 60, n. 4, p. 583-592. 2007b.

MOTOKI, A., PETRAKIS, G.H., SICHEL, S.E., CARDOSO, C.E., MELO, R.C., SOARES, R.S., MOTOKI, K.F. Landform origin of the Mendanha Massif, State of Rio de Janeiro, Brazil, based on the geomorphological analyses by summit level map technique. Geociências, Rio Claro, v. 27, n. 1, p. 99-115, 2008 a.

MOTOKI, A., SICHEL, S.E., SAVI, D.C., AIRES, J.R. Intrusion mechanism of tabular intrusive bodies of subhorizontal discordant emplacement of the Cabo Frio Island and the neighbour areas, State of Rio de Janeiro, Brazil. Geociências, Rio Claro, v. 27, n. 2, p. 207-218, 2008b.

MOTOKI, A., SICHEL, S.E., SOARES, R.S., NEVES, J.L.P., AIRES, J.R. Geological, lithological, and petrographical characteristics of the Itaúna Alkaline Intrusive Complex, São Gonçalo, State of Rio de Janeiro, Brazil, with special attention of its emplace mode. Geociências, Rio Claro, v. 27, n. 1, p. 33-44, 2008 c.

MOTOKI, A., SICHEL, S.E., SOARES, R.S., AIRES, J.R., SAVI, D.C., PETRAKIS, G.H., MOTOKI, K.F. Vent-filling pyroclastic rocks of the Mendanha, the Itaúna, and the Cabo Frio Island, State of Rio de Janeiro, Brazil, and their formation process based of the conduit implosion model. Geociências, Rio Claro. v. 27, n. 3, p. 451-467, 2008d.

MOTOKI, A., SICHEL, S.E., CAMPOS, T.F.C., SRIVASTAVA, N.K., SOARES, R.S. Present-day uplift rate of the Saint Peter and Saint Paul Islets, Equatorial Atlantic Ocean. REM-Revista Escola de Minas, Ouro Preto, v. 62, n. 3, p. 331-342, 2009a.

MOTOKI, A., SICHEL, S.E., PETRAKIS, G.H. Genesis of the tabular xenoliths along contact plane of the mafic dykes of Cabo Frio area, State of Rio de Janeiro, Brazil: Thermal delamination or hydraulic shear fracturing? Geociências, Rio Claro, v. 28, n. 1, p. 15-26, 2009b.

MOTOKI, A., SICHEL, S.E., VARGAS, T., AIRES, J.R., IWANUCH, W., MELLO, S.L.M., MOTOKI, K.F.; SILVA, S., BALMANT, A., GONÇALVES, J. Geochemical evolution of the felsic alkaline rocks of Tanguá, Rio Bonito, and Itaúna intrusive bodies, State of Rio de Janeiro, Brazil. Geociências, Rio Claro, v. 29, n. 3, p. 291-310, 2010.

MOTOKI, A., GERALDES, M.C., IWANUCH, W., VARGAS, T., MOTOKI, K.F., BALMANT, A., RAMOS, M.N. Pyroclastic dyke and welded crystal tuff of the Morro dos Gatos alkaline intrusive complex, State of Rio de Janeiro, Brazil. REMRevista Escola de Minas, Ouro Preto, v.65, n.1, p. 35-45, jan-mar, 2012.

NASCIMENTO, M.A.L., SOUZA, Z.S., PAIVA, H.S., SILVEIRA, F.V., VASCONCELOS, P.M.P. O Pico do Cabugi: raiz de um vulcão extinto no sertão do Rio Grande do Norte. In: CONGRESSO BRASILEIRO DE GEOLOGIA, 43. Anais... Aracaju. Sociedade Brasileira de Geologia, v. 1. p. 262-262, 2006.

PAIVA, H.S., SOUZA, Z.S., SILVEIRA, F.V. Caracterização geológica do edifício vulcânico Cabugi - RN. In: CONGRESSO BRASILEIRO DE GEOLOGIA, 42. Anais... Araxá. Sociedade Brasileira de Geologia. CD-ROM, 1p., 2004.

PETRAKIS, G.H., MOTOKI, A., SICHEL, S.E., ZUCCO, L.L., AIRES, J.R., MELLO S.L.M. Ore geology of special quality gravel and artificial sand: exemples of alkaline syenite of Nova Iguaçu, State of Rio de Janeiro, and rhyolite of Nova Prata, State of Rio Grande do Sul, Brazil. Geociências, Rio Claro, v. 29, n. 1, p. 21-32, 2010.

ROBINSON, C.S. Geology of Devils Tower, Wyoming. Bulletin of the United States Geological Survey. p 1021, 1956.

ROCHA, J.C.A.D., NASCIMENTO, M.A.L. Pico do Cabugi como produto ecoturístico e geoturístico no Rio Grande do Norte. Golbal Geoturismo, v. 3, n.2, 2007. 22p.

ROLFF, P.A.A. O pico vulcânico do Cabugi, Rio Grande do Norte. Departamento Nacional de Produção Mineral, Divisão de Geologia e Mineração, Notas Preliminares e Estudos, v. 126, p. 1-26, 1965.

SCHILLING, M., CONCEIÇÃO, R.V., MALLMANN, G., KOESTER, E., KAWASHITA, K., HERVÉ, F., MORATA, D., MOTOKI, A. Spinel-facies mantle xenoliths from Cerro Redondo, Argentine Patagonia: Petrographic, geochemical, and isotopic evidence of interaction between xenoliths and host basalt. Lithos, v. 82, n. 3-4, p. 485-502. 2005. 
SIAL, A.N. The Rio Grande do Norte alkali-olivine basalt association, northeast Brazil. Revista Brasileira de Geociências, São Paulo, v. 6, p. 1-14, 1976.

SIAL, A.N. Major and trace chemistry of the Tertiary basaltic suite of Rio Grande do Norte and Paraíba, northeast Brazil. Jornal de Mineralogia, v. 7, p. 119-128, 1978.

SIAL, A.N., LONG, L.E., PESSÔA, D.A.R., KAWASHITA, K. Potassium-argon ages and strontium isotope geochemistry of Mesozoic and Tertiary basaltic rocks, northeastern Brazil. In: ACADEMIA BRASILEIRA DE CIÊNCIAS, Anais... v. 53, n. 1, p. 115-122, 1981.

SICHEL, S.E., MOTOKI, A., SAVI, D.C., SOARES, R.S. 2008. Subvolcanic ventfilling welded tuff breccia of the Cabo Frio Island, State of Rio de Janeiro, Brazil. REM-Revista Escola de Minas, Ouro Preto, v. 61, n. 4, p. 423-432, 2008.

SILVEIRA, F.V. Magmatismo cenozóico da porção central do Rio Grande do Norte, NE do Brasil. Natal: Universidade Federal do Rio Grande do Norte, 2006. 195p. (Tese de Doutorado - Unpublished)

SILVEIRA, F.V., SOUZA, Z.S., PAIVA, H.S. Ocorrência de corpos peridotíticos e rochas vulcânicas associadas na região de Lajes - Pedro Avelino / RN, extremo nordeste da Província Borborema. In: CONGRESSO BRASILEIRO DE GEOLOGIA, 41. Anais... João Pessoa: Sociedade Brasileira de Geologia, p. 425, 2002.

SOUZA, Z.S., JARDIM, E.F., MARTIN, H. Metagranitóides do Complexo Caicó, NE do Brasil: aspectos geoquímicos de um megmatismo cálcico-alcalino na transição Arqueano - Paleoproterozóico. Boletim do Instituto de Geociências da Universidade de São Paulo, v. 18, p. 55-57, 1996. (Publicação Especial).

SOUZA, Z.S., PAIVA, H.S., SILVEIRA, F.V. O edifício vulcânico Cabugi, Terciário do Rio Grande do Norte. In: SIMPÓSIO SOBRE VULCANISMO E AMBIENTES ASSOCIADOS, 2. Boletim de Resumos... Belém, 2002. p. 105.

SOUZA, Z.S., VASCONCELOS, P.M.P., NASCIMENTO, M.A.L.,, SILVEIRA, F.V., PAIVA, H.S., DIAS, L.G.S., THIED, D., CARMO, I.O. ${ }^{40} \mathrm{Ar} /{ }^{39} \mathrm{Ar}$ geochronology of Mesozoic and Cenozoic magmatism in NE Brazil. Short Papers of the IV South American Symposium on Isotope Geology, Salvador, v. 2. p. 691-694, 2003.

SOUZA, Z.S., VASCONCELOS, P.M.P., SILVEIRA, F.V. Vulcanismo no NE do Brasil: reavaliação da Formação Macau. In: SIMPÓSIO DE GEOLOGIA DO NORDESTE, 22. Atas... Natal: Sociedade Brasileira de Geologia, v. 20, p. 189, 2007.

SPRY, R.A. The origin of columnar jointing, particularly in basalt flows. Australian Journal of Earth Sciences, v. 8, n. 2, p. 191-216, 1962.

Artigo recebido em 21 de maio de 2011. Aprovado em 20 de janeiro de 2012. 